\title{
Originals
}

\section{Diabetic Nephropathy and Arterial Hypertension}

\author{
H.-H. Parving, ${ }^{1,2,5}$, A. R. Andersen ${ }^{1,3}$, U. M. Smidtt ${ }^{5}$, B. Oxenbøll ${ }^{1}$, B. Edsberg ${ }^{4}$ and J. Sandahl Christiansen ${ }^{1}$ \\ ${ }^{1}$ Steno Memorial Hospital, Gentofte, Department of Medicine ${ }^{2} \mathrm{~F}$ and ${ }^{3} \mathrm{~B}$, Herlev Hospital, University of Copenhagen, and Departments of \\ ${ }^{4}$ Medicine $\mathrm{C}$ and ${ }^{5} \mathrm{Clinical}$ Physiology, Bispebjerg Hospital, Copenhagen, Denmark
}

\begin{abstract}
Summary. The relationship between arterial blood pressure and diabetic nephropathy was examined in 61 Type 1 (insulindependent) diabetic patients ( 22 females and 39 males). All patients fulfilled the following criteria: persistent proteinuria ( $>0.5 \mathrm{~g} /$ day), onset of diabetes before 31 years of age, age $<42$ years, serum creatinine $<130 \mu \mathrm{mol} / \mathrm{l}$, and no antihypertensive treatment. Thirty Type 1 diabetic patients without persistent proteinuria but matched for sex, age, ideal body weight and duration of diabetes, and 30 healthy subjects matched for sex, age and ideal body weight were also studied as controls. The diabetic patients with persistent proteinuria had elevated
\end{abstract}

blood pressures $(146 / 96 \pm 17 / 10 \mathrm{mmHg}$, mean $\pm \mathrm{SD})$ compared with $123 / 75 \pm 11 / 8 \mathrm{mmHg}$ in diabetic patients without persistent proteinuria, and normal subjects $(120 / 77 \pm$ $6 / 6 \mathrm{mmHg} ; p<0.001$ for each). Diastolic blood pressure $\geqslant 95 \mathrm{mmHg}$ was found in $51 \%$ of the group with persistent proteinuria. Elevated arterial blood pressure is frequently present in young Type 1 diabetic patients with diabetic nephropathy and normal serum creatinine.

Key words: Type 1 diabetes, diabetic nephropathy, hypertension, proteinuria, serum creatinine.
Light microscopic evidence of diabetic glomerulosclerosis is found in approximately $90 \%$ of Type 1 (insulindependent) diabetic patients with diabetes of duration $>10$ years $[1,2]$; however, only half of these patients will develop persistent proteinuria and a decline in glomerular filtration rate, i.e. diabetic nephropathy [3-5]. Hypertension is not a feature of the early stages of diabetic renal disease, as reviewed by Ireland et al. [4]. Furthermore, hypertension is reported to be frequently absent in Type 1 diabetic patients until renal failure is advanced $[6,7]$. In contrast, we have recently demonstrated that a rise in arterial blood pressure to a hypertensive level (i.e. diastolic blood pressure $\geqslant 95 \mathrm{mmHg}$ ) is frequently present in young Type 1 diabetic patients with diabetic nephropathy and glomerular filtration rate $>80 \mathrm{ml} / \mathrm{min}$ per $1.73 \mathrm{~m}^{2}$ [8]. This finding emerged from a prospective study of glomerular filtration rate, proteinuria and arterial blood pressure.

In an attempt to clarify the causes of the above mentioned controversy, we have performed a study of arterial blood pressure in all young Type 1 diabetic patients with persistent proteinuria $(>0.5 \mathrm{~g} /$ day) and normal serum creatinine $(<130 \mu \mathrm{mol} / \mathrm{l})$, who visited the outpatient clinic at the Steno Memorial Hospital from September 1978 to December 1980.

\section{Subjects and Methods}

Records were examined of all Type 1 diabetic patients with proteinuria (positive Albustix) visiting the outpatient clinic at Steno Memorial Hospital from September 1978 to December 1980. All patients fulfilling the following criteria were asked to participate in the present study: persistent proteinuria (see below), onset of Type 1 diabetes before age 31 years, current age $<42$ years, serum creatinine $<130 \mathrm{\mu mol} / 1$, and no antihypertensive treatment. Sixty-one patients fulfilled all the selection criteria (Table 1 ). Originally 81 patients were recorded, but 13 patients were excluded because of elevated serum creatinine, four because of antihypertensive treatment, and three patients did not attend the outpatient clinic.

Thirty Type 1 diabetic patients without proteinuria and normal serum creatinine, matched for sex, age and duration of diabetes and 30 healthy subjects (hospital staff, medical students) matched for sex and age were also studied (Table 1). All diabetic patients were ketosisprone and were treated with twice daily insulin. None of the patients were taking any other drugs.

All diabetic patients and healthy subjects gave their informed consent, and the experimental design was approved by the Ethical Committee.

Persistent proteinuria was defined as urinary protein excretion of $>0.5 \mathrm{~g} / 24 \mathrm{~h}$ on four consecutive visits to the out-patient clinic (interval between visits $8-12$ weeks).

Diabetic nephropathy was diagnosed clinically if the following criteria were fulfilled: persistent proteinuria, presence of diabetic retinopathy, duration of diabetes of $>10$ years, and no clinical or laboratory evidence of disease of the kidneys or the renal tract other than diabetic glomerulosclerosis. Six patients with diabetes duration 
Table 1. Clinical data of Type 1 diabetic patients with and without diabetic nephropathy, and normal subjects

\begin{tabular}{|c|c|c|c|c|c|c|c|c|c|c|}
\hline & $\begin{array}{l}\text { Number of } \\
\text { patients }\end{array}$ & Sex & $\begin{array}{l}\text { Age } \\
\text { (years) }\end{array}$ & $\begin{array}{l}\text { Ideal body } \\
\text { weight } \\
(\%)\end{array}$ & $\begin{array}{l}\text { Insulin dose } \\
\left(\mathrm{IU} \cdot \mathrm{kg}^{-1} \cdot \mathrm{day}^{-1}\right)\end{array}$ & $\begin{array}{l}\text { Onset of } \\
\text { diabetes } \\
\text { (years) }\end{array}$ & $\begin{array}{l}\text { Duration of } \\
\text { diabetes } \\
\text { (years) }\end{array}$ & Retinopathy & & $\begin{array}{l}\text { Serum } \\
\text { creatinine } \\
(\mu \mathrm{mol} / 1)\end{array}$ \\
\hline $\begin{array}{l}\text { Patients with } \\
\text { diabetic } \\
\text { nephropathy }\end{array}$ & $\begin{array}{l}22 \\
39\end{array}$ & $\begin{array}{l}\mathrm{F} \\
\mathrm{M}\end{array}$ & $\begin{array}{l}29 \pm 7 \\
31 \pm 7\end{array}$ & $\begin{array}{l}92 \pm 7 \\
99 \pm 7\end{array}$ & $\begin{array}{l}0.71 \pm 0.23 \\
0.68 \pm 0.21\end{array}$ & $\begin{array}{r}9 \pm 4 \\
13 \pm 6\end{array}$ & $\begin{array}{l}20 \pm 7 \\
18 \pm 6\end{array}$ & $\begin{array}{l}\text { Nil } \\
\text { Background } \\
\text { Proliferative }\end{array}$ & $\begin{array}{l}(n=6) \\
(n=22) \\
(n=33)\end{array}$ & $\begin{array}{l}87 \pm 10 \\
95 \pm 10\end{array}$ \\
\hline $\begin{array}{l}\text { Patients without } \\
\text { diabetic } \\
\text { nephropathy }\end{array}$ & $\begin{array}{l}10 \\
20\end{array}$ & $\begin{array}{l}\mathrm{F} \\
\mathrm{M}\end{array}$ & $\begin{array}{l}32 \pm 6 \\
28 \pm 6\end{array}$ & $\begin{array}{l}97 \pm 8 \\
97 \pm 7\end{array}$ & $\begin{array}{l}0.65 \pm 0.09 \\
0.69 \pm 0.13\end{array}$ & $\begin{array}{l}15 \pm 6 \\
11 \pm 7\end{array}$ & $\begin{array}{l}18 \pm 6 \\
17 \pm 4\end{array}$ & $\begin{array}{l}\text { Nil } \\
\text { Background } \\
\text { Proliferative }\end{array}$ & $\begin{array}{l}(n=18) \\
(n=11) \\
(n=1)\end{array}$ & $\begin{array}{l}75 \pm 9 \\
89 \pm 11\end{array}$ \\
\hline Normal subjects & $\begin{array}{l}10 \\
20\end{array}$ & $\begin{array}{l}\mathrm{F} \\
\mathrm{M}\end{array}$ & $\begin{array}{l}30 \pm 6 \\
31 \pm 6\end{array}$ & $\begin{array}{l}91 \pm 6 \\
98 \pm 8\end{array}$ & & & & & & \\
\hline
\end{tabular}

Results expressed as mean $\pm \mathrm{SD}$

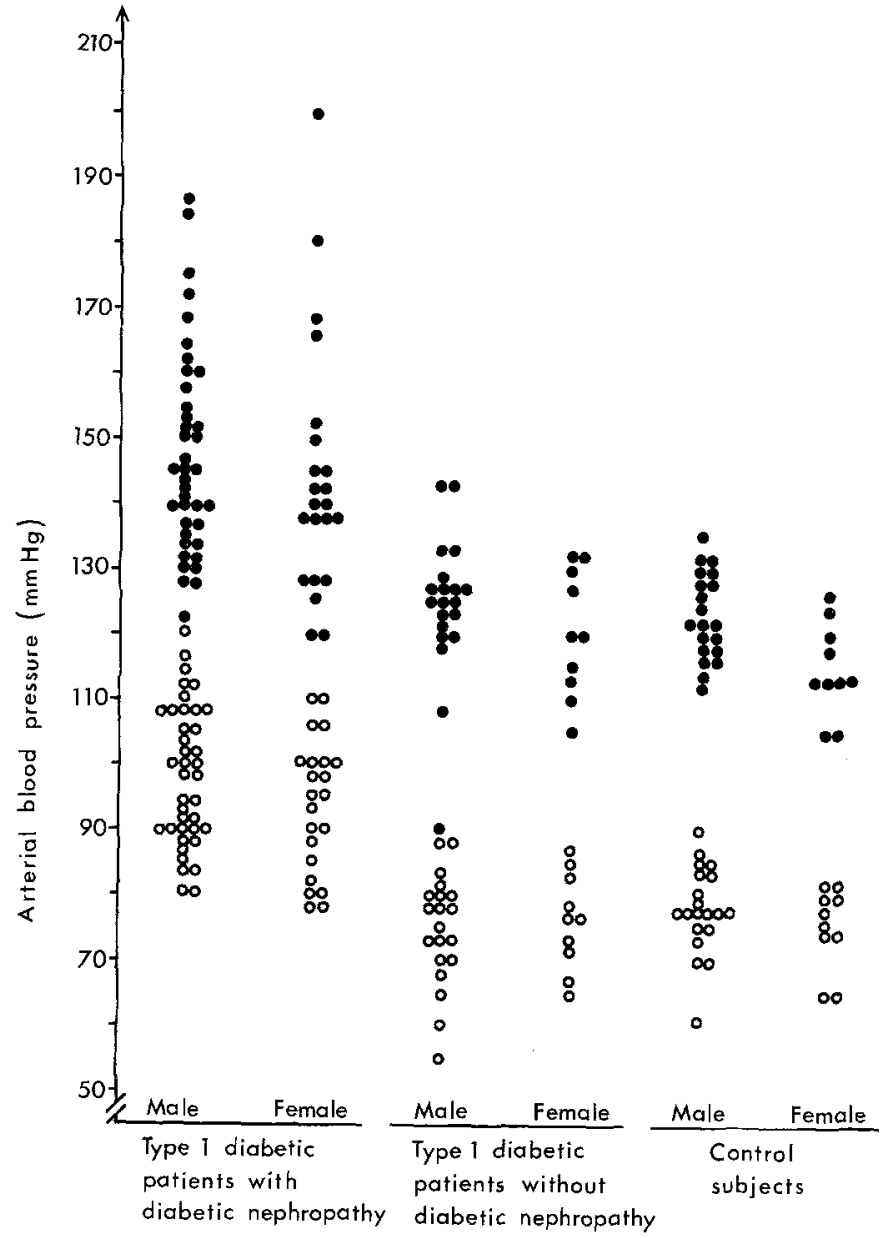

Fig. 1. Systolic $(\bullet)$ and diastolic $(O)$ blood pressures in young Type 1 (insulin-dependent) diabetic patients with $(n=61)$, and without $(n=$ 30) diabetic nephropathy, and in healthy subjects $(n=30)$

$<10$ years did not have retinopathy. A kidney biopsy was therefore performed and in all six cases diffuse diabetic glomerulosclerosis was found.

The blood pressure was measured with a standard clinical sphygmomanometer (cuff $25 \times 12 \mathrm{~cm}$ ) on the right arm with the subject in the supine position for at least $10 \mathrm{~min}$. The blood pressure was measured three times on two separate occasions within 1 month. Pressure was recorded to the nearest $5 \mathrm{mmHg}$; diastolic blood pressure was taken as the disappearance of the Korotkoff sounds (phase 5). Blood pressure in each subject was calculated as the mean of all six measure ments. Conditions of measurement were the same for all three groups studied.

Serum creatinine concentration was measured using a time-reaction technique [9]. The upper limit of normal for serum creatinine concentration in our laboratory is $120 \mu \mathrm{mol} / 1$ (females) and $130 \mu \mathrm{mol} / 1$ (males).

Arterial hypertension was considered to be present when diastolic blood pressure $\geqslant 95 \mathrm{mmHg}$.

Results are presented as mean \pm SD. Wilcoxon's non-parametric test for paired comparison was used for statistical analysis.

\section{Results}

Figure 1 shows the arterial blood pressure in each subject. The Type 1 diabetic patients with persistent proteinuria had elevated blood pressures $(146 / 96 \pm 17 /$ $10 \mathrm{mmHg}$, mean $\pm \mathrm{SD}$ ), compared with $123 / 75 \pm$ $11 / 8 \mathrm{mmHg}$ in the patients without persistent proteinuria $(p<0.001)$ and $120 / 77 \pm 6 / 6 \mathrm{mmHg}$ in healthy subjects $(p<0.001)$. A diastolic blood pressure $\geqslant 95 \mathrm{mmHg}$ was found in 31 of the 61 patients with persistent proteinuria. There was a tendency for a slightly lower arterial blood pressure in the females compared with the males (NS).

\section{Discussion}

Our study has revealed a high incidence of significant elevation of blood pressure in young onset Type 1 diabetic patients with diabetic nephropathy and normal serum creatinine when compared to matched Type 1 diabetic patients without proteinuria and healthy subjects. Thirty-one out of the 61 Type 1 diabetic patients (51\%) with diabetic nephropathy had a diastolic blood pressure $\geqslant 95 \mathrm{mmHg}$. Thus, our findings are in contrast with the generally accepted view that diabetic nephropathy does not usually cause hypertension until late in its clinical course [7].

Information regarding arterial blood pressure and diabetic nephropathy has come from three main sources; autopsy studies, retrospective analysis of records and prospective clinical studies. The existence of hypertension based on left ventricular hypertrophy 
and/or non-standardized blood pressure readings obtained from retrospective studies of autopsy protocols and clinical records in patients with diabetic glomerulosclerosis must be regarded as unreliable [10-12]. Bjerkelund [13] found, based on records, a slight but statistically insignificant blood pressure elevation in 138 middleaged patients with diabetic renal disease (defined as persistent proteinuria). Twenty-five percent of the patients did not have diabetic retinopathy. No information regarding kidney function and antihypertensive treatment was available. Watkins et al. [6] stated that hypertension (diastolic blood pressure $\geqslant 100 \mathrm{mmHg}$ ) is a late feature of diabetic nephropathy. This suggestion was based on a follow-up study in 16 Type 1 diabetic patients having a kidney biopsy performed 11 years previously because of proteinuria. However, five of the patients never developed persistent proteinuira, whilst hypertension was recorded in the six patients who died from uraemia. Malins [14] studied 54 female and 29 male Type 1 and Type 2 diabetic patients randomly selected due to persistent proteinuria. Renal biopsy showed diabetic glomerulosclerosis in all patients. A diastolic blood pressure $\geqslant 100 \mathrm{mgHg}$ was found in $49 \%$ of the patients. However, only six of the 83 patients studied had normal renal function at the time of the blood pressure readings. Hatch et al. [15] found arterial hypertension ( $>140 / 90 \mathrm{mmHg}$ ) in 31 out of 41 diabetic patients with persistent proteinuria and biopsy-proven diabetic glomerulosclerosis. Azotaemia was present in 33 patients, and most of the patients had Type 2 diabetes. Freedman et al. [16] carried out a large prospective study of arterial blood pressure in 1100 diabetic patients, measured under standardized conditions. Most of the patients suffered from Type 2 diabetes. Fifty-four patients with persistent proteinuria had diastolic blood pressure $>100 \mathrm{mmHg}$, accounting for $27.5 \%$ of all patients with arterial hypertension in the study. Unfortunately, no information was given regarding kidney function and the prevalence of persistent proteinuria. Keen et al. [17] evaluated the relationship between arterial blood pressure and diabetes, mainly in Type 2 diabetes. Blood pressure was measured under standardized conditions in 735 patients. A tendency for elevated blood pressure was found in those patients with persistent proteinuria, irrespective of the age groups studied. However, the blood pressure elevation did not differ significantly from diabetic patients without proteinuria. Information regarding kidney function was not presented.

The present finding of elevated arterial blood pressure in young Type 1 diabetic patients with diabetic nephropathy may reflect a causal relationship. However, it is possible that the renal disorder is accelerated in those diabetic patients who, for other reasons, lie in the upper reaches of the blood pressure range, as suggested by Keen et al. [17]. However, Deckert and Poulsen [18] have recently demonstrated that the arterial blood pressure, measured before the occurrence of per- sistent proteinuria, is almost the same in Type 1 diabetic patients who subsequently develop diabetic nephropathy compared with matched Type 1 diabetic subjects without evidence of diabetic nephropathy after more than 32 years of disease. The mechanisms involved in the rise of blood pressure in diabetic nephropathy are poorly understood, as reviewed by Christlieb [19].

Acknowledgements. This study was supported by grants from the Danish Medical Research Council, Landsforeningen for Sukkersyge, and King Christian X's Foundation.

\section{References}

1. Honey GE, Pryse-Davies J, Roberts DM (1962) A survey of nephropathy in young diabetics. Q J Med 31: 473-483

2. Thomsen AC (1965) The kidney in diabetes mellitus. Munksgaard, Copenhagen

3. Knowles HC (1974) Magnitude of the renal failure problem in diabetes. Kidney Int (Suppl) 6:2-7

4. Ireland JT, Viberti GC, Watkins PJ (1982) The kidney and renal tract. In: Keen H, Jarrett $\mathbf{J}$ (eds) Complications of diabetes, 2nd eds. Edward Arnold, London, pp 166-172

5. Deckert T, Poulsen JE, Larsen M (1978) Prognosis of diabetics with diabetes onset before the age of thirty-one. Diabetologia 14: 363-370

6. Watkins PJ, Blainey JD, Brewer DB, Fitzgerald MG, Malins JM, O'Sullivan DJ, Pinto JA (1972) The natural history of diabetic renal disease. Q J Med 41: 437-456

7. Leading article (1978) Diabetes and hypertension. Lancet 2: 138-139

8. Parving H-H, Smidt UM, Friisberg B, Bonnevie-Nielsen V, Andersen AR (1981) A prospective study of glomerular filtration rate and arterial blood pressure in insulin-dependent diabetics with diabetic nephropathy. Diabetologia 20: 457-461

9. Larsen K (1972) Creatinine assay by a reaction-kinetic principle. Clin Chim Acta 41: 209-217

10. Laipply TC, Eitzen O, Dutra FR (1944) Intercapillary glomerulosclerosis. Arch Int Med 74: 354-364

11. Henderson LL, Spraue RG, Wagener HP (1947) Intercapillary glomerulosclerosis. Am J Med 3: 131-144

12. Mendelow H, Britt G (1956) Intercapillary glomerulosclerosis. A clinico-pathologic study. J Mt Sinai Hosp 23:663-670

13. Bjerkelund CJ (1951) Diabetic renal disease. Acta Med Scand 139: 133-145

14. Malins J (1968) Clinical diabetes mellitus. Eyre and Spottiswoode, London, pp 152-185

15. Hatch FE, Watt MF, Kramer NC, Parrish AE, Howe JS (1961) Diabetic glomerulosclerosis. Am J Med 31: 216-230

16. Freedman P, Moulton R, Spencer AG (1958) Hypertension and diabetes mellitus. Q J Med 27: 293-305

17. Keen H, Track NS, Clive Sowry GS (1975) Arterial pressure in clinically apparent diabetics. Diabet Metabol (Paris) 1:159-178

18. Deckert T, Poulsen JE (1981) Diabetic nephropathy: Fault or destiny? Diabetologia 21 : 178-183

19. Christlieb AR (1973) Diabetes and hypertensive vascular disease. Am J Cardiol 32: 592-606

Received: 8 February 1982

and in revised form: 18 August 1982

Dr. H.-H. Parving

Department of Medicine $F$

Herlev Hospital

2730 Herlev, Denmark 